NBER WORKING PAPER SERIES

\title{
LABOR VERSUS CAPITAL IN \\ TRADE-POLICY DETERMINATION: \\ THE ROLE OF GENERAL-INTEREST AND SPECIAL-INTEREST POLITICS
}

\author{
Pushan Dutt \\ Devashish Mitra \\ Working Paper 10084 \\ http://www.nber.org/papers/w10084 \\ NATIONAL BUREAU OF ECONOMIC RESEARCH \\ 1050 Massachusetts Avenue \\ Cambridge, MA 02138 \\ November 2003
}

We thank Chris Magee, Doug Nelson, Nina Pavcnik, Alan Taylor, Henry Van Egteren, Daniel Traca and participants at the GEP Conference on "Trade and Labor Perspectives on Worker Turnover" (University of Nottingham, June 2003) for useful discussions and gratefully acknowledge the SSHRC (410-2003-1309) for financial support. The standard disclaimer applies.

The views expressed herein are those of the authors and not necessarily those of the National Bureau of Economic Research.

(C2003 by Pushan Dutt and Devashish Mitra. All rights reserved. Short sections of text, not to exceed two paragraphs, may be quoted without explicit permission provided that full credit, including $(\subset$ notice, is given to the source. 
Labor Versus Capital in Trade-Policy Determination:

The Role of General-Interest and Special-Interest Politics

Pushan Dutt and Devashish Mitra

NBER Working Paper No. 10084

November 2003

JEL No. F10, F11, F13

\begin{abstract}
Trade policy depends on the extent to which the government wants to redistribute income as well as on a country's overall factor endowments and their distribution. While the government's desire to redistribute income itself is dependent on asset distribution, it is to a large extent also driven by the partisan nature of the government, i.e., whether it is pro-labor or pro-capital. Using cross-country data on factor endowments, inequality and government orientation, we find that, conditional on inequality, left-wing (pro-labor) governments will adopt more protectionist trade policies in capitalrich countries, but adopt more pro-trade policies in labor-rich economies than right-wing (procapital) ones. Also, holding government orientation constant, higher inequality is associated with higher protection in capital-abundant countries while it is associated with lower protection in laborabundant countries. These results are consistent with the simultaneous presence of both general- as well as special-interest politics as determinants of protection within a two-factor, two-sector Heckscher-Ohlin framework. Overall, various statistical tests support an umbrella model (that combines both the general-interest as well as special-interest models) over each of the individual models.
\end{abstract}

Pushan Dutt

Department of Economics

Universityof Alberta

Edmonton, Alberta

Canada, T6G 2H4

pdutt@ualberta.ca
Devashish Mitra

Department of Economics

The Maxwell School of Citizenship and

Public Affairs

Syracuse University

133 Eggers Hall

Syracuse, NY 13244

and NBER

dmitra@maxwell.syr.edu 


\section{Introduction}

Most trade economists like to think about the impact of trade and trade policy in terms of their consequences for capitalists and workers. For example, in the presence of intersectoral factor mobility, raising barriers to international trade in goods will help capital and hurt labor or vice versa, depending on whether the country's comparative advantage is in labor- or capital-intensive products. Thus, an important effect and sometimes an important objective of trade policy is the redistribution of income from capital to labor or vice versa. One possible determinant of such redistribution is the political valence or the partisanship of the government, which refers to whether the government is pro-labor (left-oriented), pro-capital (right-oriented) or relatively neutral (centrist). In other words, there is always a tendency for governments to redistribute, through trade policy and other policy instruments, income to their constituents and supporters from the rest of the society. This aspect of policy determination is driven by what we call "specialinterest" politics.

In this context, it is interesting to note that the tradition of linking political parties to classes (factors of production) can be traced back to traditional theories of party systems where party classification is generally studied in terms of the capital-labor (or sometimes, the rural-urban) dichotomy (Lipset and Rokkan (1997)). For over two decades now, scholars have analyzed the effects of partisanship on macroeconomic policy. The most important contributions in this area are those by Hibbs (1977), Alt (1985) and Alesina (1987), all of whom, in this context, have focused on the trade-off between inflation and unemployment. Recent research on the effects of partisanship, however, has gone beyond macroeconomic policy. In particular, using OECD data, Garret (1998) looks at how globalization has changed the way in which fiscal policy responds to partisanship, while Swank (2002) looks at how the response of welfare expenditure to globalization depends on the nature of the state and the relative strengths of interest groups. ${ }^{1}$

\footnotetext{
${ }^{1}$ In studying the effects of partisanship, Adsera and Boix (2002) model endogenous trade regime (free trade versus autarky) as well as government size and show the possibility of multiple equilibria - autarky (free trade)
} 
However, in studying class- or factor-based "special-interest" politics, one needs to take account of the fact that there might not be a clear division in society between workers and capitalists. While raw labor power might be pretty uniformly distributed, human and physical capital ownership might not be so. The existence of such an asset distribution, in which each individual owns some of both factors, means that everyone in society is a capitalist and a worker to relatively different degrees. Thus people with extremes in relative factor ownership are close to being either pure workers or pure capitalists. However, such heterogeneity in asset ownership can exactly be the basis for varying levels of protection, depending on the degree of inequality. This can be derived in a model where policy is determined by majority voting (Mayer (1984)). In other words, due to the inherently unequal nature of asset and income distribution (where the majority of the individuals have their asset holdings below the mean), any government will have a tendency to redistribute income from those who look more like capitalists to those who look more like workers. This does not necessarily arise from the altruistic nature of the government but rather from its self interest to get elected or survive by winning the support of the majority. This second aspect of policy determination is called "general-interest" politics and can either reinforce or neutralize the forces of special interest politics, depending on the government's political valence or ideology.

The precise manner in which the political ideology or valence affects trade policy is the following. The effect of an increase in the leftist orientation of the government can be viewed as an increase in the weight on labor welfare relative to capital welfare in the government's objective function (which for the purpose of this analysis is defined as a weighted sum of worker and capitalist welfare). ${ }^{2}, 3$ This increase in the labor-welfare weight results in policies that are more pro-labor and that make the domestic terms of trade move in favor of the labor-intensive sector. with small (large) government and an authoritarian free-trade, small-government regime.

2 This is the political-support function approach popularized by Hillman (1989) and Van Long and Vousden (1991).

3 In a world with all people owning both factors, but to different extents, we can just assume weights given to different individuals in the government's objective function to be monotonic in individual relative factor endowments. More specifically, in the objective function of a left-wing (right-wing) party in power, the weight on each individual's welfare will be decreasing (increasing) in the individual capital-to-labor endowment ratio. Thus, our hypothesis on political ideology can be given a fairly general interpretation. 
In a capital-abundant country, the labor-intensive good is the importable good and therefore, an increase in the leftist orientation of the government will result in a rise in import protection. In a labor-abundant country, however, the capital-intensive good is the importable and the laborintensive good is the exportable. Therefore, an increase in leftist orientation in such a country that calls for a change in the domestic price ratio in favor of the labor-intensive exportable good will result in a decline in import protection. We call this the "special-interest" hypothesis.

The median-voter prediction (which we call the "general-interest" hypothesis) we test is also about cross-country variations in levels of trade barriers and not about the actual orientations (signs) of the levels. More precisely, a simple comparative-static exercise in the Mayer-HeckscherOhlin framework (as in Mayer (1983)) shows that an increase in inequality (the difference between the mean and the median capital-labor ratio), holding constant the economy's overall relative endowments, raises trade barriers in capital-abundant economies and lowers them in capitalscarce economies. An increase in inequality increases the general demand for redistribution from capital to labor. This can be achieved through trade policies that increase further the factor reward to labor but reduce the reward to capital, which in turn is achieved by increasing the domestic relative price of the labor-intensive good in a two sector, two factor Heckscher-Ohlin economy. Thus, an increase in inequality would result in a tightening of trade restrictions in capital-abundant economies and their reduction in capital-scarce countries.

While in Dutt and Mitra (2002a) we explicitly focus on the empirical investigation of the median-voter (general-interest) model of trade policy, in another paper, Dutt and Mitra (2002b), we investigate the predictions of a special-interest model purely based on political ideology. We now address the question whether these two models are complements or substitutes in predicting trade policy. One possibility is that ideology and inequality are correlated, and therefore, these models are observationally equivalent, i.e., they make roughly the same prediction and hence are substitutes. The other possibility is that there is extra information from each of the models and so a combination of the two models, which we call the "umbrella" model, is a better predictor of 
trade policy than each of the individual models, that are complementary to each other.

We examine the two hypotheses (general-interest and special-interest) within a unified model that potentially can nest both. For this empirical investigation, we use cross-country data on relative factor endowments (capital per worker), political ideology, inequality and different measures of protection. We perform standard F-tests as well as use Akaike, Schwarz and Amemiya criteria to evaluate the umbrella model relative to the component models. The overall picture that emerges from our analysis is that each component model provides information in addition to the other component model and so the umbrella model generally dominates the two components. Thus both special-interest politics and general-interest politics are complementary explanations of overall protection and also determinants of welfare levels of workers and capitalists.

The contribution of our paper is two-fold. Firstly, our results uncover a robust empirical regularity in the relationship between trade protection, inequality and political ideology, thereby adding to the literature on political economy of trade policy. Also, we believe that this is the first paper in the political economy literature that provides empirical evidence of the simultaneous operation of complementary channels of special- and general-interest politics in policy determination.

\section{Theoretical Framework}

We now outline the two theoretical components of our "umbrella" econometric model. These are discussed in detail in Dutt and Mitra (2002a and b).

Consider a two-factor, two-sector, small-open, Heckscher-Ohlin economy. Both goods require both capital and labor in their production carried out under constant returns to scale. On the demand side, individual preferences are taken to be identical and homothetic. We also assume that tariff revenues are distributed in proportion to the factor incomes earned by individuals. 


\subsection{Special-Interest Politics}

For simplicity, we assume that there are two kinds of factor owners, workers (who only own labor) and capitalists (who only own capital). The government chooses the level of the import tariff to maximize its objective function which is a weighted sum of the aggregate welfare of workers and capital. Our main comparative static exercise here is to see how this tariff varies with the government's weight on labor welfare (relative to the welfare of capitalists). This leads us to the following proposition:

Proposition 1: Holding other things constant, an increase in the left orientation (prolabor bias) of the government leads to more restrictive or less open trade policies in capital-abundant countries, while it leads to less restrictive or more open trade policies in capital-scarce economies.

The above result is very intuitive. An increase in left orientation always results in an increase in redistribution through policies that would benefit labor. In a capital-abundant country, the importable is the labor-intensive good and an increase in redistribution from capital to labor would increase the bias of policies in favor of the importable sector. In a labor-abundant economy, the importable sector is the capital-intensive sector and hence more redistribution towards labor requires policies that are more biased against the importable sector.

\subsection{General-Interest Politics}

We now change our assumption about asset ownership. For simplicity, we assume that each individual owns one unit of labor. However, all people are also allowed to own capital but differ in their capital ownership. ${ }^{4}$ Assuming that the voters differ only along a single dimension, namely in their relative capital-labor endowment and that there are no voting costs (and imposing standard

\footnotetext{
${ }^{4}$ As mentioned in the introduction, our special-interest model can easily be extended to a world with all people owning both factors but to different extents. In such a context, we can just assume weights given to different individuals in the government's objective function to be monotonic in individual relative factor endowments. Thus, there is virtually no loss of generality involved in the statement of proposition 1.
} 
regularity conditions ${ }^{5}$ ), the tariff under majority voting can be obtained using the median voter theorem and is the one that maximizes the utility of the individual with the median relative capital-labor endowment in the economy.

It is easy to see in this framework that an increase in inequality always results in an increase in the demand for redistribution through policies that would benefit labor at the expense of capital. In a capital-abundant country, the importable is the labor-intensive good and an increase in the demand for redistribution from capital to labor would represent a demand for policies that increasingly favor the importable sector. In a labor-abundant economy, the importable sector is the capital-intensive sector and hence more redistribution towards labor requires policies that are more biased against the importable sector. This leads us to the following proposition whose empirical validity, along with that of proposition 1, we test in this paper:

Proposition 2: Holding other things constant, an increase in inequality leads to more restrictive or less open trade policies in capital-abundant countries, while it leads to less restrictive or more open trade policies in capital-scarce economies.

\section{Econometric Methodology}

We now write down an estimating equation that can nest the results of both propositions 1 and 2. As we see above, the relationships of protection with inequality and ideology change sign at critical values of the capital-labor ratio. In countries with high $(K / L)$ ratios, left-wing ideology of the government and trade restrictiveness should be positively related, but when $(K / L)$ is low there is an inverse relationship between these two variables. A priori, we do not know at what level of $(K / L)$, this relationship changes sign. Besides, in countries with high $(K / L)$ ratios, inequality and trade restrictiveness should be positively related, but when $(K / L)$ is low there is an inverse relationship between these two. Again, a priori, we do not know at what level of $(K / L)$, this relationship changes sign. The following "umbrella" specification can help us with the exact

\footnotetext{
5 See Mayer (1984).
} 
location of these turning points (critical values of the capital-labor ratio) of protection-ideology and protection-inequality relationships:

$T R_{i}=\alpha_{0}+\alpha_{1} I_{\text {deology }}+\alpha_{2} I_{\text {deology }} \times(K / L)_{i}+\alpha_{3} I N E Q_{i}+\alpha_{4} I N E Q_{i} \times(K / L)_{i}+\alpha_{5}(K / L)_{i}+\epsilon_{i}$

where $T R_{i}$ is the extent of trade restrictions in country $i, I_{d e o l o g} y_{i}$ is a measure of the extent of the government's left-wing ideology, $I N E Q_{i}$ is the level of inequality and $(K / L)_{i}$ the capital-labor ratio. ${ }^{6}, 7$ The inclusion of $(K / L)$ as a separate variable in addition to its cross products with ideology and inequality allows $\frac{\partial T R_{i}}{\partial(K / L)_{i}}$ and the sum of the variable components of $\frac{\partial T R_{i}}{\partial(\text { Ideology })_{i}}$ and $\frac{\partial T R_{i}}{\partial(I N E Q)_{i}}$ to differ in sign. Otherwise, they are restricted to having the same sign.

Taking the partial derivative of $T R_{i}$ with respect to Ideology $y_{i}$ and $I N E Q_{i}$ respectively, we have

$$
\frac{\partial T R_{i}}{\partial(\text { Ideology })_{i}}=\alpha_{1}+\alpha_{2}(K / L)_{i}, \frac{\partial T R_{i}}{\partial(I N E Q)_{i}}=\alpha_{3}+\alpha_{4}(K / L)_{i}
$$

The prediction of the comparative static exercise summarized in proposition 1 is that $\alpha_{1}<0$ and $\alpha_{2}>0$ such that $\alpha_{1}+\alpha_{2}(K / L)_{i} \gtrless 0$ as $(K / L)_{i} \gtrless(K / L)^{*}$ where $(K / L)^{*}=-\alpha_{1} / \alpha_{2}$ is the turning point capital-labor ratio determined endogenously from the data, given our estimating equation. Another requirement for the prediction to hold is that $(K / L)^{*}$ should lie within the range of values of $(K / L)$ in the dataset, i.e., $(K / L)^{M I N}<(K / L)^{*}<(K / L)^{M A X}$. Similarly from proposition $2, \alpha_{3}<0$ and $\alpha_{4}>0$ such that $\alpha_{3}+\alpha_{4}(K / L)_{i} \gtrless 0$ as $(K / L)_{i} \gtrless(K / L)^{* *}$ where $(K / L)^{* *}=-\alpha_{3} / \alpha_{4}$ is the turning point capital-labor ratio for inequality and again has to be within the range of values of $K / L$ in our dataset.

We perform Hausman tests to investigate the possible endogeneity of the capital-labor ratio with respect to trade protection, as suggested by a two-sector Solow model. Also, our measures of inequality are the income Gini-coefficient and the median quintile's share in national income or

\footnotetext{
${ }^{6}$ We could not find any non-monotonicities with respect to $K / L$ by including an additional term $(K / L)^{2}$. We did not detect any non-linearities (at $15 \%$ and even higher levels of significance) in any of our variables when we performed the Ramsey Reset test for all our regressions, both with and without controls.

7 In our estimation, we use the capital-labor ratios in natural logs (whose use results in very few outliers) and not in levels (which result in a very large number of outliers).
} 
expenditure, both of which are indirect measures of asset inequality (or equality) since they are actually measures of income inequality. ${ }^{8} \quad$ There is the possibility of reverse causation running from trade policy to income inequality. Therefore, we also perform Hausman tests to check for the endogeneity of inequality. The Hausman test suggests that endogeneity of the capital labor ratio needs to be corrected for, which we do by performing two-stage least squares through instrumentation of the capital-labor ratio and its interaction terms. The Hausman test does not suggest any endogeneity problems associated with inequality and therefore, we do not provide any estimation results based on instrumenting it.

Since it may be argued that democracies are more likely to be responsive to both generalinterest considerations (for votes) and to special-interest considerations (for campaign contributions) we then also investigate whether this model works better in democracies than in dictatorships.

Finally our component models can be written as follows:

$$
\begin{gathered}
T R_{i}=\beta_{0}+\beta_{1} \text { Ideology }_{i}+\beta_{2} \text { Ideology }_{i} \times(K / L)_{i}+\beta_{3}(K / L)_{i}+u_{i} \\
T R_{i}=\gamma_{0}+\gamma_{1} I N E Q_{i}+\gamma_{2} I N E Q_{i} \times(K / L)_{i}+\gamma_{3}(K / L)_{i}+v_{i}
\end{gathered}
$$

The expected signs on the coefficients of inequality, ideology and their interaction with the capital-labor ratio (and the relationship among them) are the same as those in equation 1. Clearly, equations (3) and (4) are special cases of (1) through restrictions put on additional variables to equal zero. We compare these restricted models to the umbrella model using a variety of Bayesian and non-Bayesian criteria.

\footnotetext{
8 The only measure of asset inequality on which cross-country data is available is the land-Gini. However, using data on land-ownership inequality directly in our regressions is not very meaningful, especially in a Heckscher-Ohlin framework.
} 


\section{Data Sources and Some Basic Statistics}

Our dependent variable is trade protection and our independent variables of interest are a measure of ideological orientation, inequality in income distribution, the capital-labor ratio, and indicators for democracy and political rights. The analysis averages all variables for the decade of the 1980s. Data on income distribution are very sparse and available for only two or three years for the majority of the countries in the decade of the $80 \mathrm{~s}$, which prevents us from running panel regressions.

To test for the robustness of our results, we use a variety of trade policy measures: total import duties collected as a percentage of total imports (IMPORT DUTY), an average tariff rate calculated by weighing each import category by the fraction of trade in that category (TARIFF), a coverage ratio for non-tariff barriers to trade (QUOTA), an indirect measure of trade restrictions - the magnitude of trade flows relative to GDP, defined as $(X+M) / G D P$, and the newly available Hiscox-Kastner measure. While IMPORT DUTY and $(X+M) / G D P$ are taken from the World Development Indicators, TARIFF and QUOTA (both available for only one point in time for each country in the 80's) are taken from Barro and Lee (1994) and the Hiscox-Kastner measure of protection from Hiscox and Kastner (2002). Hiscox and Kastner have created two alternative measures of protection using the importing-country-specific and time-specific effects in two versions of the gravity model, one being the standard gravity model and the other an ammended one with relative factor endowment differentials being used as additional variables to capture factor-proportions type effects. In this paper, we present results using the Hiscox-Kastner measure from their basic gravity model. ${ }^{9}$ The advantage of this measure is that it captures the implicit protection through substitutes (including domestic policies adopted) of standard trade policy measures that governments use once they have committed to tariff levels in international agreements. We certainly believe that even if trade policy is determined through multilateral

\footnotetext{
${ }^{9}$ Results using the Hiscox-Kastner measure from their ammended model are qualitatively the same.
} 
negotiations, domestic special-interest and general-interest considerations can be an important determinant of what kind of trade policy a country commits to in these negotiations. ${ }^{10}$ For those who do not buy this argument, the use of the Hiscox-Kastner measure will be useful.

The data on political orientation are obtained from the Database of Political Institutions (DPI) (Beck et al, 2001) which is a large cross-country database of political institutions that covers 177 countries over 25 years, 1971-1995. We use the ideological orientation ('Left', 'Center' or 'Right') of the chief executive (that of the chief executive's party or when considered appropriate that of the chief executive himself/herself) for political systems classified as presidential in the database, that of the largest government party for systems classified as parliamentary, and the average of these two orientations for systems classified as assembly-elected president. ${ }^{11}$ Cardinality tests fail to reject the hypothesis that ideology can be treated as cardinal (See Dutt and Mitra (2002b) for details). In light of the efficiency gains to treating ideology as cardinal, we recoded the ideological orientation of the government of each country for each single year to reflect the extent to which the relevant government authority can be classified as 'leftist' - left was coded as 3 , center as 2 and right as 1 . For the cross-sectional regressions, we take the average of this variable for the 80's. Therefore, our ideology variable in the regressions is best interpreted as the extent to which the policy and decision-making authority can be considered left wing with higher numbers signifying a more pro-labor orientation. Treating ideology as cardinal has the added advantage in that it captures the variation in the proportion of years a country had regimes of various ideologies (which ordinal variables would not).

To measure inequality we use the Gini-coefficient which is a broader measure than the inter-

\footnotetext{
10 It can be argued that some countries in our sample may have committed to GATT bindings several years earlier, and that for these countries domestic political considerations are irrelevant in determining trade policies. Our analysis using the QUOTA measure, as well as the Hiscox-Kastner measure that captures other policies (such as industrial, labor etc.) that can implicitly act as trade barriers, circumvents this criticism. Secondly, it turns out that only for 8 countries in our dataset the GATT bindings would have been binding constraints, i.e., most other countries either had not bound their tariffs by early 80 's or their actual tariffs were below their GATT commitments. The countries for which past bindings would have mattered in the 1980's are the US, Japan, Canada and the members of the EU by the 1970's. When we throw away these countries or use a dummy for them, our results are qualitatively the same.

${ }^{11}$ For a series of robustness checks on the reliability of this measure see Dutt and Mitra (2002b).
} 
pretation of inequality used in the theoretical framework in section 2. As a robustness check, we use $Q 3$, the share of the third quintile in national income. This is an inverse measure of inequality (or rather a measure of equality) and so the signs of the coefficients of this variable and its interaction with $K / L$ are expected to be the reverse of those obtained with the Gini coefficient. These data were obtained from Dollar and Kraay (2002) whose primary source is the UN-WIDER World Income Inequality Database, which in turn, is a substantial extension of the income distribution dataset constructed by Deininger and Squire (1996). The data on capital-labor ratios are obtained from Easterly and Levine who use aggregate investment and depreciation data to construct capital per worker series for 138 countries. $^{12}$

For a measure of democracy, we use the Freedom House (Gastil) measure of democracy that provides a subjective classification of countries on a scale of 1 to 7 on political rights, with higher ratings signifying less freedom. Finally, as instruments, the additional variables used are the natural logarithm of the savings rate and the population growth rate obtained from the World Development Indicators. Note that the population growth rate and the savings rate are parameters in the Solow growth model in which the steady state per-capita capital stock is determined endogenously.

\section{$5 \quad$ Results}

\subsection{OLS Estimation Results from Umbrella and Stand-Alone Models}

Table 1 reproduces the results from Dutt and Mitra (2002a) and Dutt and Mitra (2002b). ${ }^{13}$ As we can see both the special-interest model (first 5 columns of table 1 ) and the general-interest model (columns 6-10 in table 1) are individually supported. The critical capital-labor ratio ranges

\footnotetext{
12 We also tried the Easterly-Levine capital per worker data that uses disaggregate sectoral investment and depreciation data to arrive at more accurate measures. However, the country coverage for the second measure is much smaller resulting in very low degrees of freedom.

13 Note that the country coverage in this paper and Dutt and Mitra (2002a, 2002b) is different for two reasons. First, we use an updated version of the inequality dataset constructed by Deininger and Squire (1996). Second, we only included those countries in our sample that had data on both political ideology and income inequality. This facilitates comparison across models and circumvents any problem of sample-selection bias. Note that due to the different final datasets used, the results from the stand-alone models in this paper, though qualitatively extremely similar to those in Dutt and Mitra (2002a, b), are quantitatively a little different.
} 
from 8.9 to 10.7 for the special-interest model and from 8.1 to 9.0 for the general-interest model. Note that the critical capital-labor ratio is itself an estimate and has a standard error. For most of our regressions, the 2 standard error confidence-interval around this estimate includes the median and mean capital-labor ratios. While the models in table 1 as a whole are statistically significant, for import duty and $(X+M) / G D P$ the individual coefficients on inequality and the interaction term (in the general-interest model) are not significant.

We next turn to the umbrella model where we jointly estimate the significance of specialinterest and general-interest considerations in trade policy determination. The results are shown in table 2. All our regression models as a whole are significant at the $5 \%$ level. As predicted, across all measures of protection save import duty, we find that the variables relevant to the special-interest model (left-wing ideology and its interaction with the capital-labor ratio) and the variables relevant to the general-interest model (inequality and its interaction with the capitallabor ratio) are strongly significant. Further as predicted, we obtain negative signs on ideology and inequality and positive signs on each of the interaction terms. For $(X+M) / G D P$ - a measure of openness - the signs are reversed and significant. We now obtain two critical capital-labor ratios - one where the relationship between left-wing ideology and trade protection switches sign and one where the relationship between inequality and trade protection switches from negative to positive. The critical capital-labor ratio ranges from 8 to 11.2. As the table shows these critical values are close to each other and include the median capital-labor ratio within the 2 standard error confidence-interval. The $R^{2}$ ranges from 0.17 in the case of quotas, to 0.47 for the HiscoxKastner measure. The results are the strongest and most robust for tariffs and quotas, which are the most direct measures of trade restrictions and for the Hiscox-Kastner measure which also captures implicit protection through domestic policy substitutes (in addition to explcit protection through tariff and non-tariff trade barriers). 


\subsection{Model Comparisons: Umbrella vs. Stand-Alone Models}

Next we examine whether the umbrella model is an improvement on the individual special-interest and the general-interest models. First, the adjusted $R^{2}$ is highest in the umbrella model for tariffs, the Hiscox-Kastner measure and $(X+M) / G D P$. For import duty the adjusted $R^{2}$ is highest in the special-interest model as is the case for quotas even though the difference here between the adjusted $R^{2}$ of the special interest and the umbrella models is only 0.0019 . Second, we run regressions of the actual measure of trade policy on the predicted values of protection from the general- and special-interest models thrown in together (run in levels and logs) and found both coefficients to be individually and jointly significant for all trade policy measures, except import-duty. This suggests that the two individual models complement one another. Third, we see in table 2 that for all measures of protection, both the ideology and inequality related variables are individually significant. The joint F-test for the inequality-related variables (inequality and its interaction with the capital-labor ratio, which are the additional variables of the general-interest model)) shows that they are jointly significant for the Hiscox-Kastner measure and $(X+M) / G D P$, while the joint test for the ideology-related variables (the additional variables of the special-interest model) shows their joint significance for all protection measures except for import duty. What is remarkable here is that for our most comprehensive measure of the protection, namely the Hiscox-Kastner measure, both the joint tests show strong significance of additional variables from each of the stand-alone models. Finally, we used the Akaike Information Criterion (AIC) and the Bayesian Information Criterion (BIC) as metrics for model selection (umbrella versus component models). ${ }^{14}$ We find that AIC selects the umbrella model for tariffs, Hiscox-Kastner and $(X+M) / G D P$ over each of the stand-alone models whereas it selects the special-interest model over the umbrella model for quotas and import-duty. The same is case for the BIC except that it selects the special-interest

\footnotetext{
14 There is no best criteria; different model-selection criteria simply represent different balances in the tradeoff between parsimony and goodness of fit. For example, the BIC penalises complexity relatively more than does the AIC.
} 
model in the case of tariffs as well. ${ }^{15}$ None of these criteria ever suggest that the general-interest model is better than the umbrella.

On the whole, there seems to be strong evidence to reject the assertion that general-interest considerations on their own can explain variations in protectionism. Special-interest considerations play a very strong role as well and the umbrella model always does better than the stand alone general-interest model. However, when comparing the umbrella model to the special-interest model, we find that support for the umbrella model is contingent on the measure of trade policy. For tariffs, the Hiscox-Kastner measure and $(X+M) / G D P$ the umbrella model is strongly favored while for quotas the special-interest model seems more appropriate. Given the individual significance of the general-interest terms (inequality and inequality interacted with capital-labor ratio), given that for a majority of the measures the umbrella model is preferred in terms of AIC and $\mathrm{BIC}$, and since there is no single best model selection criterion, we may conclude that the special-interest and general-interest considerations are complementary in accounting for variations in trade restrictions. ${ }^{16}$

\subsection{Robustness Checks}

First, we added political rights of Gastil as an independent variable to control for the extent of democracy. This variable turns out to be insignificant and does not alter our earlier results qualitatively. ${ }^{17}$ Second, we use an alternative measure of inequality - the share of the third quintile (Q3) in national income. Since this is an inverse measure of inequality the signs predicted are the reverse of those that we obtain from using the Gini coefficient. In particular, we expect a positive

\footnotetext{
15 The adjusted $R^{2}$ based on Amemiya's Prediction Criterion selects the umbrella model for import duty, HiscoxKastner and $(X+M) / G D P$ and the special-interest model for tariffs and quotas. This statistic penalizes $R^{2}$ more heavily than does the usual adjusted $R^{2}$ for each additional degree of freedom used on the right-hand-side of the equation.

${ }^{16}$ It may be argued that in countries with high levels of inequality only left-wing governments get elected. This would imply that the political ideology of the government is endogenous with respect to the level of inequality. We failed to find support for such an argument: First, the correlation between left-wing ideology and income inequality is only -0.1. Second, we regressed ideology on inequality, generated residuals and used these residuals as a proxy for left-wing ideology in the umbrella model. Our results remain completely unaffected.

17 Using the Polity measure of democracy instead of the Gastil measure makes little difference given the high correlation between them.
} 
coefficient on $Q 3$ and a negative coefficient on $Q 3$ interacted with capital-labor ratio. We see from table 3 that both special-interest and general-interest considerations significantly influence trade policies in the predicted direction for tariffs, quotas and the Hiscox-Kastner measure, marginally for $(X+M) / G D P$, but not for import duty. Even in the case of import duty, the model as a whole is strongly significant and we are able to account for $36 \%$ of the variation in import duties across countries. Further, we obtain critical capital-labor ratios that are indistinguishable from those we obtained in table 2 .

Third, in a dynamic context (for example in a multi-sector Solow model), the capital-labor ratio may be endogenous with respect to trade policy. Protection, by affecting the production structure, can affect accumulation and the steady state level of the capital stock. In fact, Hausman test suggest the endogeneity of the capital-labor with respect to the measures of trade protection. Therefore, we perform a two-stage, least-squares estimation where we instrument capital-labor ratio by the $\log$ of the population growth rate and the log of the savings rate. ${ }^{18}$ We do not instrument for inequality since the Hausman test indicates that the endogeneity of inequality is not really a problem. As table 4 shows, across all measures of protection the prediction of both models are supported. The relevant terms are all significant and the critical capital-labor ratios are again very close to the mean and the median capital-labor ratios. More importantly, we see that now for the import duty measure as well, we obtain support for the umbrella model. The last row of table 4 provides the Basmann test of overidentifying restrictions which validates the quality of our chosen instruments.

We again uses the AIC and BIC model selection criterion to compare the umbrella model with each of the component models separately. Our results now unambiguously favor the umbrella model - across all measures of protection and across model selection criteria the umbrella model

\footnotetext{
18 Hausman tests did not indicate any endogeneity problems for either of the interaction terms. For these Hausman tests, we used ideology and inequality interacted with the saving and population growth rates as additional instruments. In fact with the savings rate and the population growth rate and their interaction with inequality and ideology, the estimating equation is overidentified, so that we were able to perform the appropriate tests for overidentifying restrictions and confirm that our instruments are valid and of good quality.
} 
is preferred to the special-interest model and to the general-interest model. Thus, once we control for the endogeneity of the capital-labor ratio all ambiguity that we noted in the previous section (when comparing the umbrella model to the special-interest model) is removed.

\subsection{The Interaction of Special and General Interest Considerations}

We already have evidence on the complementary nature of special and general interest concerns in influencing trade policies. While both special-interest and general-interest considerations seem to be significant in the formulation of trade policies, their relative importance may vary. If the objective of a political party is to win elections, a way to do so is to simply adopt policies that are favored by the median voter. While politicians may win elections partly because they advocate popular policies, a successful campaign also requires money for advertising, polling and "get-thevote-out" efforts. Thus contributions and support from core constituents may be indispensable, so that partisan motives come into play. Therefore, the relative importance of the special-interest and general-interest considerations will depend on the degree to which median voter and partisan interests and identities coincide or are in conflict. In this section we investigate this issue in greater detail. Our overall findings reinforce the complementary nature of special-interest and general-interest politics in trade policy determination.

\subsubsection{Special Interest Considerations in Countries with High vs. Low Levels of Inequality}

We analyze whether special-interest concerns are more important in countries with high inequality or in countries that have a more egalitarian distribution of income. Our intuition is that in countries with very high-levels of inequality, governments must adopt the policies of the median voter to ensure re-election or to prevent revolution. ${ }^{19}$ This will be true regardless of whether the party in power is pro-labor or pro-capital in its ideological orientation. On the other hand, in countries with low levels of inequality, special interest considerations will play a dominant role

\footnotetext{
19 See Acemoglu and Robinson (2001) as to why dictatorships may be responsive to majoritarian concerns. In their paper, as inequality rises, dictators opt for redistributive policies in order to mitigate the risk of revolutions and social unrest.
} 
and we would expect the partisan model to have significantly greater explanatory power.

First, we partition the sample of countries into low-inequality and high-inequality countries (based on the median Gini coefficient) and estimate separate special-interest models for each of these sub-samples. From table 5 we see that for the majority of the regressions, the special-interest model has greater explanatory power and that the estimated coefficients are individually as well as jointly significant in countries with low levels of inequality. In contrast, the special-interest model fares poorly in countries with high levels of inequality and the signs are not only insignificant but in many cases, the estimated coefficients have the wrong sign as well.

Next, we generate residuals from the special-interest regressions in table 1 and regress the absolute values of these residuals on the inequality variable. These regressions show that for three measures of trade policy (tariff, quota, and the Hiscox-Kastner measure), the absolute residuals are significantly higher in more unequal countries. Moreover, the predicted values of protection using the coefficient estimates from the same regressions have a much greater correlation with the actual values for the low-inequality sample (Gini coefficient less than 40). Across all measures of protection, the correlations double or treble when we switch from the high-inequality to the lowinequality sample. Both findings suggest that the fit of the partisan model is superior in countries with low levels of inequality.

\subsubsection{General Interest Considerations in Countries with Pro-Labor vs. Pro-Capital Governments}

Next we test the efficacy of the median voter models and evaluate its explanatory power separately in countries where pro-labor governments are in power as opposed to countries where pro-capital governments hold power. In countries with pro-labor governments in power, special-interest and general-interest considerations overlap since the median voter is relatively labor-rich. On the other hand, in countries where right-wing governments are in power the policymakers face a trade-off. Policies that pander to their constituents (the capitalists) whom they depend upon for campaign contributions and/or votes may alienate the majority (who are relatively rich in labor). This in 
turn entails future losses in elections. This suggests that since left-wing governments pay greater emphasis to the needs of labor groups, the median voter model will be a better fit in countries where pro-labor governments are in power. However, it can also be argued that left-wing governments who have already adopted pro-labor policies have less room to manoeuvre so that a unit increase in inequality is likely to lead to a smaller adjustment in trade policies. Pro-capital governments whose policies are further from that preferred by the labor-rich median voter have greater flexibility in adjusting trade policies following an increase in inequality. We take an agnostic view on this issue and pose it as an empirical question.

As table 6 shows, we find that the relevant coefficients for the general-interest model are significant for tariffs and $(X+M) / G D P$ regardless of whether pro-labor or pro-capital governments are in power. But for quotas and the Hiscox-Kastner measure, inequality and its interaction with the capital-labor ratio is significant only when pro-labor governments are in power. We again fail to find any significant effect of inequality on import duties across countries regardless of the government's ideological orientation. Next we generate residuals from the general-interest regressions in table 1 and regress the absolute values of these residuals on the ideology variable. Only for $(X+M) / G D P$ did we find that these residuals are significantly greater in pro-capital countries. Finally, after generating predicted values from the general-interest regressions in table 1, we find that their correlation with actual protection in countries with pro-labor governments is roughly similar to the correlation for countries with pro-capital governments. ${ }^{20}$

To summarize, if a pro-labor government is in power, the welfare of the median voter coincides with the partisan interests of the government. The weight of the evidence suggests that the general-interest model is more significant and has marginally greater explanatory power in such countries. On the other hand, when a right-wing government is in power, there is a conflict between the government's partisan interests and majoritarian concerns and the median voter

\footnotetext{
20 Only for the case of tariffs is the correlation between actual and predicted values higher in the pro-capital sample (0.7) as compared to the pro-labor sample (0.46). However, the individual coefficient estimates are significant only in the pro-labor sample.
} 
model's predictive power seems to diminish.

\subsection{The Role of Democracy}

Next we investigate whether redistributive concerns, driven by special interest politics or generalinterest politics, are more important in democracies or in dictatorships. Democratic governments, to ensure their re-election, may adopt policies that benefit the majority and their electoral base (groups that provide large blocks of votes and/or provide campaign contributions). Dictatorships on the other hand face few such incentives.

In order to investigate the relationship between redistributive concerns and the extent of democracy, we generate residuals from our umbrella model and then regress the absolute values of these residuals on the democracy/dictatorship (political rights) variable. These regressions show that for all our direct measures of trade protection (tariff, quota, import duty, and Hiscox-Kastner measure), the absolute residuals are higher for dictatorships. Next, we generate predicted values of protection from the coefficient estimates in table 2 and find that their correlation with the actual values is considerably lower for the dictatorship sample (Gastil measure above 4) than for the democracy sample (the rest). Both findings suggest that the umbrella model fits democracies better. $^{21}$

\section{Conclusion}

Trade policy depends on the extent to which the government wants to redistribute income as well as on overall factor endowments and their distribution. In turn, the government's desire to redistribute income is dependent on asset distribution, an important determinant of the demand for redistribution. This link between the extent of redistribution and asset distribution can easily be demonstrated through the use of a median-voter type model, which captures the desire of in-

\footnotetext{
21 Using the Polity measure of democracy gives us identical results given its high correlation with the Gastil measure. However, neither of these measures are significant if we add them to our regressions in Table 2. This suggests that the extent of democracy matters less in determining the level of trade policy, but more in terms of adding to the explanatory power of the 2 models under consideration here.
} 
cumbents to be re-elected through the use of populist policies. This type of a model is essentially a short-hand way of capturing the effects of electoral competition. And finally, it captures the idea that even dictators can survive only with the help of popular support. However, policy determination, to a large extent, is also driven by the partisan nature of the government, i.e., whether it is pro-labor or pro-capital. Parties and governments have their own ideologies about whether to promote growth by encouraging capital accumulation or to promote egalitarianism by protecting labor interests. Further, since different groups in society form constituents of and contribute to different parties, special-interest concerns also become important in policy determination. We find simultaneous support for both aspects of politics in trade policy determination.

Using cross-country data on factor endowments, inequality and government orientation, we find that, conditional on inequality, left-wing (pro-labor) governments will adopt more protectionist trade policies in capital-rich countries, but adopt more pro-trade policies in labor-rich economies than right-wing (pro-capital) ones. Also, holding government orientation constant, higher inequality is associated with higher protection in capital-abundant countries while it is associated with lower protection in labor-abundant countries. These results hold simultaneously within a unified econometric model of trade policy determination that simultaneously captures special- and general-interest factors as determinants of protection within a two-factor, two-sector Heckscher-Ohlin framework. Overall, using various Bayesian and non-Bayesian statistical tests, we find strong support for using such an umbrella model over stand-alone special-interest or general-interest models, especially when we control for the endogeneity of the capital-labor ratio with respect to the protectionism measures. Finally we show that the umbrella model works better for democracies than for dictatorships, showing the greater relevance of both special- and general-interest factors in democracies relative to dictatorships. 


\section{References}

Acemoglu, Daron and James A. Robinson, 2001, "A Theory of Political Transitions," American Economic Review, 91(4), 938-963.

Adsera, Alicia and Carles Boix, 2002, "Trade, Democracy and the Size of the Public Sector," International Organization 56(2), 229-262.

Alesina, Alberto, 1987, "Macroeconomic Policy in a Two Party System as a Repeated Game," Quarterly Journal of Economics 102, 651-678.

Alt, James, 1985, "Political Parties, World Demand and Unemployment: Domestic and International Sources of Economic Activity," American Political Science Review 79, 10161040 .

Beck, Thorsten; George Clarke; Alberto Groff and Philip Keefer, 2001, "New Tools and New Tests in Comparative Political Economy: The Database of Political Institutions," forthcoming, World Bank Economic Review.

Deininger, Klaus and Lyn Squire, 1996, "A New Data Set Measuring Income Inequality." The World Bank Economic Review 10(3), 565-591.

Dutt, Pushan and Devashish Mitra, 2002a, "Endogenous Trade Policy Through Majority Voting: An Empirical Investigation," Journal of International Economics 58(1), 107-134.

Dutt, Pushan and Devashish Mitra, 2002b, "Political Ideology and Endogenous Trade Policy: An Empirical Investigation," NBER Working Paper No. w9239

Garrett, Geoffrey., 1998, Partisan Politics in the Global Economy, New York: Cambridge University Press.

Hibbs, Douglas A., 1977, "Political Parties and Macroeconomic Policy," American Political Science Review 7, 1467-1487.

Hillman, Arye L., 1989, The Political Economy of Protection (Harwood Academic, London and New York), 1989.

Hiscox, Michael J., 2001, International Trade and Political Conflict: Commerce, Coalitions and Mobility, Princeton, NJ: Princeton University Press.

Hiscox, Michael J.. and Scott Kastner, 2002, "A General Measure of Trade Policy Orientations: Gravity-Model-Based Estimates for 82 Nations, 1960-1992", mimeo, Harvard University.

Magee, Stephen P.; William Brock and Leslie Young, 1989, Black Hole Tariffs and Endogenous Policy Theory (Cambridge University Press, Cambridge and New York).

Schonhardt-Bailey, Cheryl, 1991, Specific Factors, Capital Markets, Portfolio Diversification and Free Trade, World Politics 43(4), 545-69.

Swank, Duane, 2002, Global Capital, Political Institutions and Policy Change in Developed Welfare States, New York: Cambridge University Press.

Van Long, Ngo. and Neil Vousden, 1991,"Protectionist responses and declining industries," Journal of International Economics 30 (1-2), 87-103. 


\begin{tabular}{|c|c|c|c|c|c|}
\hline & \multicolumn{5}{|c|}{$\begin{array}{c}\text { Table 1: The Individual Models } \\
\text { The Special Interest Model }\end{array}$} \\
\hline & Tariff & Quota & Import Duty & Hiscox-Kastner & $(X+M) / G D P$ \\
\hline ideology & $\begin{array}{l}-0.45^{* * *} \\
(0.096)\end{array}$ & $\begin{array}{c}-0.591^{* * *} \\
(0.219)\end{array}$ & $\begin{array}{c}-11.361^{* *} \\
(6.448)\end{array}$ & $\begin{array}{c}-38.273^{* * *} \\
(11.903)\end{array}$ & $\begin{array}{c}59.421^{* * *} \\
(28.27)\end{array}$ \\
\hline ideology ${ }^{*}$ capital-labor ratio & $\begin{array}{c}0.045^{\star * *} \\
(0.009)\end{array}$ & $\begin{array}{c}0.055^{* * *} \\
(0.02)\end{array}$ & $\begin{array}{l}1.278^{* *} \\
(0.666)\end{array}$ & $\begin{array}{c}4.115^{\star * \star} \\
(1.202)\end{array}$ & $\begin{array}{c}-6.533^{* * *} \\
(3.07)\end{array}$ \\
\hline capital-labor ratio & $\begin{array}{l}-0.15^{\star * *} \\
(0.025)\end{array}$ & $\begin{array}{c}-0.157^{\star * *} \\
(0.058)\end{array}$ & $\begin{array}{c}-6.134^{* * *} \\
(1.505)\end{array}$ & $\begin{array}{c}-13.734^{* * *} \\
(3.273)\end{array}$ & $\begin{array}{c}26.07^{* * *} \\
(8.798)\end{array}$ \\
\hline constant & $\begin{array}{c}1.641^{* * *} \\
(0.263)\end{array}$ & $\begin{array}{c}1.812^{* * *} \\
(0.64)\end{array}$ & $\begin{array}{c}67.543^{\star * *} \\
(14.922)\end{array}$ & $\begin{array}{c}160.608^{* * *} \\
(33.24)\end{array}$ & $\begin{array}{c}-212.268^{* * *} \\
(82.393)\end{array}$ \\
\hline No. of observations & 59 & 58 & 62 & 54 & 79 \\
\hline$R^{2}$ & 0.36 & 0.14 & 0.35 & 0.42 & 0.35 \\
\hline F-statistic & $20.39^{* * *}$ & $2.44^{* *}$ & $15.15^{* * *}$ & $13.82^{* * *}$ & $12.28^{* * *}$ \\
\hline \multirow[t]{3}{*}{ critical capital-labor ratio } & 10 & 10.7 & 8.9 & 9.3 & 9.1 \\
\hline & \multicolumn{5}{|c|}{ The General Interest Model } \\
\hline & Tariff & Quota & Import Duty & Hiscox-Kastner & $(X+M) / G D P$ \\
\hline inequality & $\begin{array}{c}-0.026^{* * *} \\
(0.01)\end{array}$ & $\begin{array}{c}-0.031^{* * *} \\
(0.012)\end{array}$ & $\begin{array}{l}-0.406 \\
(0.644)\end{array}$ & $\begin{array}{c}-2.315^{\star * *} \\
(0.837)\end{array}$ & $\begin{array}{c}4.285^{* * *} \\
(1.798)\end{array}$ \\
\hline inequality ${ }^{*}$ capital-labor ratio & $\begin{array}{c}0.003^{* * *} \\
(0.001)\end{array}$ & $\begin{array}{l}0.004^{* * *} \\
(0.001)\end{array}$ & $\begin{array}{c}0.05 \\
(0.063)\end{array}$ & $\begin{array}{c}0.253^{* * *} \\
(0.089)\end{array}$ & $\begin{array}{c}-0.475^{* * *} \\
(0.21)\end{array}$ \\
\hline \multirow[t]{2}{*}{ capital-labor ratio } & $\begin{array}{c}-0.145^{\star * \star} \\
(0.044)\end{array}$ & $\begin{array}{c}-0.145^{\star * *} \\
(0.057)\end{array}$ & $\begin{array}{l}-5.0^{* *} \\
(2.88)\end{array}$ & $\begin{array}{c}-13.346^{* * *} \\
(3.793)\end{array}$ & $\begin{array}{c}28.817^{* \star *} \\
(9.36)\end{array}$ \\
\hline & $\begin{array}{c}1.474^{* * *} \\
(0.466)\end{array}$ & $\begin{array}{l}1.354^{* * *} \\
(0.567)\end{array}$ & $\begin{array}{l}55.188^{* *} \\
(30.434)\end{array}$ & $\begin{array}{c}153.69^{* * *} \\
(37.33)\end{array}$ & $\begin{array}{l}-234.9^{* * *} \\
(81.225)\end{array}$ \\
\hline No. of observations & 59 & 58 & 62 & 54 & 79 \\
\hline$R^{2}$ & 0.3 & 0.08 & 0.33 & 0.37 & 0.35 \\
\hline F-statistic & $8.62^{* * *}$ & $2.58^{\star *}$ & $11.77^{* * *}$ & $8.83^{* * *}$ & $11.39^{* * *}$ \\
\hline critical capital-labor ratio & 9 & 8.2 & 8.1 & 9.1 & 9 \\
\hline
\end{tabular}




\begin{tabular}{|c|c|c|c|c|c|}
\hline & \multicolumn{5}{|c|}{ Table 2: The Umbrella Model } \\
\hline & Tariff & Quota & Import Duty & Hiscox-Kastner & $(X+M) / G D P$ \\
\hline \multirow[t]{2}{*}{ ideology } & $-0.367^{\star \star \star}$ & $-0.433^{\star *}$ & $-9.793^{*}$ & $-34.096^{* * *}$ & $49.506^{\star *}$ \\
\hline & $(0.114)$ & $(0.232)$ & $(6.846)$ & $(13.205)$ & $(26.57)$ \\
\hline \multirow[t]{2}{*}{ ideology ${ }^{*}$ capital-labor ratio } & $0.036^{\star * *}$ & $0.039^{* *}$ & $1.119^{*}$ & $3.673^{* * *}$ & $-5.538^{* *}$ \\
\hline & $(0.011)$ & $(0.022)$ & $(0.707)$ & $(1.377)$ & $(2.946)$ \\
\hline \multirow[t]{2}{*}{ inequality } & $-0.017^{* *}$ & $-0.019^{* *}$ & -0.284 & $-1.845^{\star * *}$ & $3.746^{* * *}$ \\
\hline & $(0.009)$ & $(0.011)$ & $(0.626)$ & $(0.786)$ & $(1.854)$ \\
\hline \multirow[t]{2}{*}{ inequality ${ }^{*}$ capital-labor ratio } & $0.002^{* *}$ & $0.002^{* *}$ & 0.034 & $0.19^{* * *}$ & $-0.408^{* *}$ \\
\hline & $(0.001)$ & $(0.001)$ & $(0.062)$ & $(0.088)$ & $(0.217)$ \\
\hline \multirow[t]{2}{*}{ capital-labor ratio } & $-0.198^{* * *}$ & $-0.205^{\star * *}$ & -7.027 & $-20.158^{* * *}$ & $39.624^{* * *}$ \\
\hline & $(0.032)$ & $(0.06)$ & $(2.93)$ & $(3.568)$ & $(11.355)$ \\
\hline \multirow[t]{2}{*}{ constant } & $2.09^{* * *}$ & $2.131^{* \star *}$ & 74.293 & $224.049^{* * *}$ & $-336.88^{* * *}$ \\
\hline & $(0.339)$ & $(0.626)$ & $(30.567)$ & $(36.162)$ & (99.638) \\
\hline No. of observations & 59 & 58 & 62 & 54 & 79 \\
\hline$R^{2}$ & 0.4 & 0.17 & 0.36 & 0.47 & 0.39 \\
\hline F-statistic & $12.98^{* * *}$ & $2.51^{* * *}$ & $10.12^{* * *}$ & $9.83^{* * *}$ & $8.07^{* * *}$ \\
\hline Joint test for inequality & 1.83 & 1.81 & 0.33 & $3.03^{* *}$ & $2.02^{*}$ \\
\hline Joint test for ideology & $4.33^{* * *}$ & $2.75^{\star * *}$ & 1.62 & $3.73^{* * *}$ & $2.43^{\star *}$ \\
\hline critical capital-labor ratio & & & & & \\
\hline $\begin{array}{r}\text { (ideology) } \\
\text { critical capital-labor ratio }\end{array}$ & 10.1 & 11.2 & 8.8 & 9.3 & 8.9 \\
\hline (inequality) & 9.3 & 8 & 8.3 & 9.7 & 9.2 \\
\hline \multicolumn{6}{|c|}{ Standard errors in parantheses; ${ }^{* * *}$ - significant at $5 \%$ level, ${ }^{* *}$ - significant at $10 \%$ level ${ }^{*}$ - significant at $15 \%$ level } \\
\hline
\end{tabular}




\begin{tabular}{|c|c|c|c|c|c|}
\hline \multicolumn{6}{|c|}{ Table 3: The Umbrella Model (Share of Median Quintile) } \\
\hline & Tariff & Quota & Import Duty & Hiscox-Kastner & $(X+M) / G D P$ \\
\hline ideology & $\begin{array}{c}-0.366^{* *} \\
(0.117)\end{array}$ & $\begin{array}{l}-0.407^{* *} \\
(0.249)\end{array}$ & $\begin{array}{c}-10.782^{*} \\
(6.674)\end{array}$ & $\begin{array}{c}-31.925^{\star * \star} \\
(13.374)\end{array}$ & $\begin{array}{c}32.063 \\
(23.612)\end{array}$ \\
\hline ideology ${ }^{*}$ capital-labor ratio & $\begin{array}{l}0.036^{* *} \\
(0.011)\end{array}$ & $\begin{array}{l}0.036^{*} \\
(0.024)\end{array}$ & $\begin{array}{l}1.165^{\star *} \\
(0.688)\end{array}$ & $\begin{array}{c}3.469^{* * *} \\
(1.391)\end{array}$ & $\begin{array}{l}-3.87^{*} \\
(2.652)\end{array}$ \\
\hline inequality & $\begin{array}{l}4.766^{*} \\
(2.93)\end{array}$ & $\begin{array}{c}9.746^{\star * *} \\
(4.4)\end{array}$ & $\begin{array}{c}140.774 \\
(237.637)\end{array}$ & $\begin{array}{l}529.916^{\star *} \\
(285.689)\end{array}$ & $\begin{array}{c}-1872.44^{* * *} \\
(582.957)\end{array}$ \\
\hline inequality ${ }^{*}$ capital-labor ratio & $\begin{array}{l}-0.541^{* *} \\
(0.311)\end{array}$ & $\begin{array}{c}-1.132^{\star * *} \\
(0.501)\end{array}$ & $\begin{array}{c}-16.27 \\
(23.615)\end{array}$ & $\begin{array}{l}-55.9^{* *} \\
(30.489)\end{array}$ & $\begin{array}{c}219.792^{* \star *} \\
(66.737)\end{array}$ \\
\hline capital-labor ratio & $\begin{array}{l}-0.045 \\
(0.065)\end{array}$ & $\begin{array}{c}0.065 \\
(0.119)\end{array}$ & $\begin{array}{l}-3.192 \\
(3.832)\end{array}$ & $\begin{array}{l}-3.808 \\
(7.037)\end{array}$ & $\begin{array}{l}-14.863 \\
(12.003)\end{array}$ \\
\hline constant & $\begin{array}{c}0.703 \\
(0.609)\end{array}$ & $\begin{array}{l}-0.149 \\
(1.085)\end{array}$ & $\begin{array}{c}42.386 \\
(36.952)\end{array}$ & $\begin{array}{c}66.689 \\
(65.156)\end{array}$ & $\begin{array}{c}146.398 \\
(107.678)\end{array}$ \\
\hline No. of observations & 59 & 58 & 62 & 54 & 79 \\
\hline$R^{2}$ & 0.4 & 0.19 & 0.4 & 0.46 & 0.45 \\
\hline F-statistic & $13.26^{* * *}$ & $2.32^{* *}$ & $10.45^{\star * *}$ & $8.34^{* * *}$ & $7.02^{* \star *}$ \\
\hline $\begin{array}{r}\text { critical capital-labor ratio } \\
\text { (ideology) } \\
\text { critical capital-labor ratio }\end{array}$ & 10 & 11.2 & 9.3 & 9.2 & 8.3 \\
\hline (inequality) & 8.8 & 8.6 & 8.7 & 9.5 & 8.5 \\
\hline Standard errors in parantheses; ${ }^{* * *}$ & ignificant a & evel, ${ }^{* *}$ - sigr & ant at $10 \%$ leve & ${ }^{*}$ - significant at 15 & level \\
\hline
\end{tabular}




\begin{tabular}{|c|c|c|c|c|c|}
\hline & \multicolumn{5}{|c|}{ Table 4: The Umbrella Model (IV Estimates) } \\
\hline & Tariff & Quota & Import Duty & Hiscox-Kastner & $(X+M) / G D P$ \\
\hline ideology & $\begin{array}{c}-0.605^{* * *} \\
(0.227)\end{array}$ & $\begin{array}{c}-0.648^{* * *} \\
(0.318)\end{array}$ & $\begin{array}{c}-32.427^{\star \star \star} \\
(16.169)\end{array}$ & $\begin{array}{c}-58.147^{\star * \star} \\
(19.036)\end{array}$ & $\begin{array}{c}123.559^{* * *} \\
(46.015)\end{array}$ \\
\hline ideology*capital-labor ratio & $\begin{array}{c}0.061^{* * *} \\
(0.023)\end{array}$ & $\begin{array}{l}0.061^{* *} \\
(0.032)\end{array}$ & $\begin{array}{c}3.465^{\star * *} \\
(1.653)\end{array}$ & $\begin{array}{c}6.052^{\star * *} \\
(1.895)\end{array}$ & $\begin{array}{c}-13.056^{\star \star *} \\
(4.702)\end{array}$ \\
\hline inequality & $\begin{array}{c}-0.048^{* * *} \\
(0.018)\end{array}$ & $\begin{array}{c}-0.052^{* * *} \\
(0.026)\end{array}$ & $\begin{array}{l}-2.258^{* *} \\
(1.398)\end{array}$ & $\begin{array}{c}-3.627^{* * *} \\
(1.298)\end{array}$ & $\begin{array}{c}9.118^{* * *} \\
(3.472)\end{array}$ \\
\hline inequality ${ }^{*}$ capital-labor ratio & $\begin{array}{c}0.005^{* * *} \\
(0.002)\end{array}$ & $\begin{array}{c}0.006^{* * *} \\
(0.003)\end{array}$ & $\begin{array}{l}0.237^{* *} \\
(0.144)\end{array}$ & $\begin{array}{c}0.362^{* * *} \\
(0.133)\end{array}$ & $\begin{array}{c}-0.951^{* * *} \\
(0.365)\end{array}$ \\
\hline capital-labor ratio & $\begin{array}{l}-0.4^{* * *} \\
(0.092)\end{array}$ & $\begin{array}{l}-0.4^{\star \star *} \\
(0.165)\end{array}$ & $\begin{array}{c}-21.293^{* * *} \\
(7.959)\end{array}$ & $\begin{array}{c}-33.442^{* * *} \\
(8.001)\end{array}$ & $\begin{array}{c}82.443^{* * *} \\
(20.703)\end{array}$ \\
\hline constant & $\begin{array}{l}4.09^{* * *} \\
(0.924)\end{array}$ & $\begin{array}{c}4.066^{* * *} \\
(1.623)\end{array}$ & $\begin{array}{c}214.027^{* * *} \\
(80.316)\end{array}$ & $\begin{array}{c}360.765^{\star \star *} \\
(83.453)\end{array}$ & $\begin{array}{c}-764.075^{\star * *} \\
(208.598)\end{array}$ \\
\hline No. of observations & 58 & 57 & 60 & 53 & 73 \\
\hline$R^{2}$ & 0.36 & 0.15 & 0.27 & 0.43 & 0.34 \\
\hline F-statistic & $6.58^{* * *}$ & 1.56 & $6.81^{* * *}$ & $9.14^{* * *}$ & $7.11^{* * *}$ \\
\hline $\begin{array}{r}\text { critical capital-labor ratio } \\
\text { (ideology) } \\
\text { critical capital-labor ratio } \\
\text { (inequality) }\end{array}$ & $\begin{array}{l}9.9 \\
9.6\end{array}$ & 10.6 & $\begin{array}{l}9.4 \\
9.5\end{array}$ & $\begin{array}{l}9.6 \\
10\end{array}$ & $\begin{array}{l}9.5 \\
9.6\end{array}$ \\
\hline Test of overidentifying restrictions & 0.187 & 0 & 2.3 & 1.36 & 0.78 \\
\hline
\end{tabular}




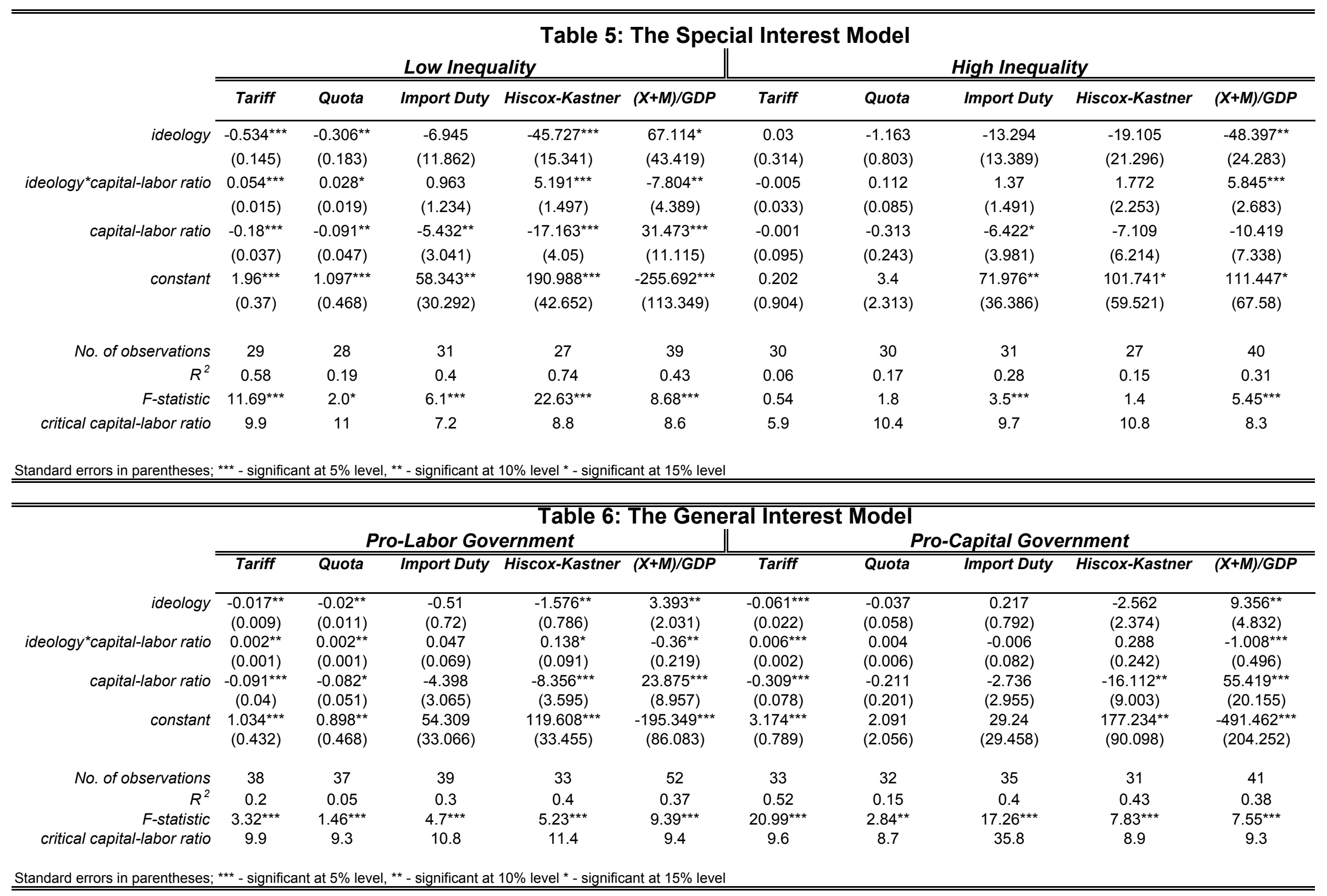

